\title{
Inequality, Marketization, and the Left: Schools Policy in England and Sweden
}

\author{
Forthcoming at the \\ European Journal of Political Research
}

Timothy Hicks*

School of Public Policy,

University College London

t.hicks@ucl.ac.uk | http://tim.hicks.me.uk/

Draft: January 23, 2015.

*I am very grateful to Nick Aylott, Lucy Barnes, Jane Gingrich, Lucas Leemann, Johannes Lindvall, Lisbeth Lundahl, Gail McElroy, Séin Ó Muineacháin, Will Phelan, Linda Rönnberg, David Rueda, Peter Stone, Lisa Vanhala, and Anne Wren for helpful discussions and comments. The paper also benefited from contributions from participants at the "Education, Religion and the Gender-vote-gap" conference (Bremen University, October 2011) and at panels at the American Political Science Association annual conference (Seattle, September 1-4 2011) and the European Political Science Association annual conference (Dublin, June 16-18 2011). 


\title{
Inequality, Marketization, and the Left: \\ Schools Policy in England and Sweden
}

\begin{abstract}
I argue that the marketization of schools policy has a tendency to produce twin effects: an increase in educational inequality and an increase in general satisfaction with the schooling system. However, I claim that the effect on educational inequality is very much stronger where prevailing societal inequality is higher. The result is that cross-party political agreement on the desirability of such reforms is much more likely where societal inequality is lower (as the inequality effects are also lower). Counterintuitively, then, countries that are more egalitarian — and so typically thought of as being more left-wing — will have a higher likelihood of adopting marketization than more unequal countries. I draw evidence from a paired comparison of English and Swedish schools policies from the 1980s to the present. Both the policy history and elite interviews lend considerable support for the theory in terms of both outcomes and mechanisms.
\end{abstract}




\section{Introduction}

The past few decades have seen the diffusion of ideas relating to competition, privatization, and marketization amongst education policy-makers across a broad range of countries (e.g. Gingrich 2011; Klitgaard 2007, 2008; Zehavi 2012a,b). While this diffusion has been relatively broad, there has been notable cross-national variation in the extent to which it has found expression in public policy. Furthermore, the ideas themselves have not been without controversy, with some seeing them as part of a 'neoliberal' onslaught that promises to undermine traditional structures of egalitarian state education systems (e.g. Ball 1993; Ladd 2002). In keeping with this, there is a common perception that marketizing reforms are inherently arrayed on the right-hand end of the standard left-right ideological dimension, especially amongst those imbued with an understanding of the political and policy experiences of countries like the UK and the USA. In these contexts - which are, themselves, typically held to be two of the more market-embracing societies in the developed world - the privatization of public education remains extremely controversial and politically divisive. All this makes it rather surprising that Sweden has adopted one of the most extensive schemes of school marketization.

The core puzzle for this paper is why such a policy would be so accepted in Sweden, where social democracy has been predominant, but so contested and polarizing in England, the home of Thatcherism. At root, I claim the explanation for these differing outcomes lies with the prevailing levels of societal inequality in the two countries. I argue that where ex ante inequality is lower, the extent to which market-based policies exacerbate this inequality is also lower — and is expected to be so by policy-making elites. As such, political actors of the left concerned with limiting inequality have far less reason to oppose the use of marketizing policies where inequality is already at a lower ebb. To the extent that they see any positive benefits to the use of markets for the delivery of public services, left-wing parties will be correspondingly more likely to support them in egalitarian societies.

Before proceeding to develop the argument in detail, it is helpful to draw connections to the existing literature in this area. To a large extent, my theoretical approach giving conceptual importance to political parties of left and right is in keeping with prominent contributions to our understandings of education politics (e.g. Ansell 2010; Busemeyer 2007; Castles 1989; Gingrich 2011; Iversen \& Stephens 2008; Zehavi 2012b). Indeed, so prominent is the partisan politics frame- 
work in this area that, studying market-oriented reforms in Scandinavia under social democratic parties, Klitgaard (2007) framed a paper around the question of "Why are they doing it?". Such a question builds naturally from prominent views of the wider phenomenon of the use of markets and privatization as being inherently right-wing (e.g. Boix 1997; Gamble 1988). ${ }^{1}$

Others have extended this basic partisan logic into richer theoretical arguments. Gingrich (2011) has developed an argument for how partisanship conditions particular features of marketization in the public sector. Klitgaard (2007) has argued that social democratic responsiveness to concerns over "welfare state legitimacy" have been important in the politics of market-oriented reforms. To this broad strand of partisanship literature, this paper adds a new theoretical perspective on why partisanship can be more or less important for policies of this sort. The claim is that prevailing prevailing socio-economic structures influence the preferences and actions of political parties in ways that have been under-explored in this area, to date. In short: inequality conditions partisanship with respect to marketization. Of course, this attention to the issue of inequality is in keeping with much broader contemporary pushes in the social sciences. Much of this work has been focused on the measuring and explaining the causes of inequality (e.g. Atkinson, Piketty, \& Saez 2011; Lupu \& Pontusson 2011; Volscho \& Kelly 2012). One contribution of this paper, then, is to provide a little more attention to the policy consequences.

\section{The Argument}

The argument built here is concerned with explaining why (especially left-wing) parties may embrace the policy of marketization in compulsory schooling systems. I adopt the partisan model of politics that has been successfully applied to education policy (e.g. Ansell 2010; Busemeyer 2007; Iversen \& Stephens 2008) and so assume that left-wing parties will tend to be relatively more concerned about inequality than right-wing parties. However, a given education policy does not necessarily have implications for inequality of educational outcomes, but may see its primary effect on another outcome dimension that I will refer to as general satisfaction with the educational system. That is, a type of 'efficiency' gain could be realised such that the relative distribution of education gains is not altered, but some or all are made more satisfied with the system. Where there exists a trade-off between inequality and this general satisfaction, left-wing

\footnotetext{
${ }^{1}$ For a slightly different perspective on the partisan politics of privatization, see Hicks (2015).
} 
parties will give relatively more weight to inequality concerns than right-wing parties. Thus, such policies that trigger the trade-off will be divisive between the left and the right. On the other hand, where a policy is deemed to impact satisfaction with the educational system without affecting inequality, it will be far less politically controversial.

What is meant by marketization in schools policy, though? Different definitions are possible, but my particular focus is on the confluence of provision of education by schools with independence from government and the ability of parents to make choices about which schools to send their children to. The independence of schools captures the extent to which they have the ability to offer distinctive types of educational experience, and may stem from freedoms relating to staffing, resource allocation, curriculum, teaching method, and the like. While there are many possible ways of increasing the independence of schools, private ownership and provision are surely at the stronger end of such policies - and the adoption of vouchers is an effective way of increasing the prevalence of private schools. Thus, while marketization does not imply privatization, privatization tends to imply marketization. These independence and choice aspects of marketization are related in the sense that school choice is more meaningful where individual schools have the ability to differentiate themselves on features of the educational experience that parents value. Thus, I focus on the combination of parental choice and the ability of schools to differentiate themselves and compete with one another for pupils; capturing both the supply and demand sides of a system. ${ }^{2}$

Why would a policy of educational marketization be related to educational satisfaction and efficiency? While there is literature supporting the contention that marketized provision can have positive effects on student outcomes, this empirical work was undertaken after the reforms studied here and so cannot provide an explanation for why these marketization policies were considered or adopted. In this light, a more appropriate approach is to focus on beliefs, especially those held by elites, as to the effects that marketization would have on educational outcomes (Jacobs 2009; Lindvall 2009). Given this, those who have emphasized the 'neoliberal' turn — in education and beyond - lend credence to the view that policy elites anticipated a positive connection between marketization and educational outcomes. As I show below in the empirical section, elites did indeed draw a positive connection between these two concepts. However, a more

\footnotetext{
${ }^{2}$ To be clear, marketization policy is distinct from, and probably orthogonal to, the issue of levels of expenditure on public schooling that has been the focus of much of the existing literature (e.g. Busemeyer 2007; Castles 1989).
} 
holistic definition of satisfaction relates to the degree to which parents (and children) perceive that schools are meeting their wishes more generally. To the extent that not all parents want the exact same school features for their children (Jacob \& Lefgren 2007), marketization will tend to provide a better match for these differential desires than more uniform patterns of state provision. Indeed, reviewing the literature on the US, Teske \& Schneider (2001: 611) find one of the "most firmly established outcomes of choice" is that "parents who choose report being more satisfied with their children's schools".

If educational marketization is related to satisfaction with the system, how and why would it be related to educational inequality? The great fear is that the introduction of marketization will increase social segregation within a schooling system, and so reduce its capacity to give all students an equal set of opportunities. An important part of my argument is that such segregation will tend to have the effect of magnifying existing societal inequalities. For this reason, the initial level of societal inequality is a key factor in determining how large the inequality-enhancing effect of educational marketization is. One reason for this has been suggested by Stephen Ball and collaborators (e.g. Ball, Bowe, \& Gewirtz 1996). In this view, there are important differences between the ways in which members of the "working class" and the "middle class" relate to schools and, consequently, how they take advantage of school choices. These authors argue that working class parents are less likely to have positive associations with schools and so are less likely to be willing or able to push their own children towards better schools. They suggest that reasons for this include deference to professional (i.e. teacher) authority, fear of failure, and even fatalistic views about the capacity of schools to "change" children. It follows from this line of reasoning that such class-based differences will be stronger where the social differences between the classes are themselves stronger. Where working class parents tend to have low levels of educational achievement and correspondingly low levels of income, their difficulties in utilising the opportunities afforded to them by school choice policies will be greater.

Another channel through which marketization may increase school segregation can be seen in Epple \& Romano (1998). They present a theoretical model in which schools compete financially for students and there are important "peer effects" such that a child's educational outcome is improved by being in a class with other more able children. Their model shows that incentives for schools are such that it makes sense for those who can charge higher fees to use some of 
the revenue to subsidise tuition for more able students. Consequently, some schools will have a mixture of students from wealthier backgrounds and more able students, while others will tend to have a mixture of the poorer and the less able. The intuition of this model - if not necessarily all of its details - captures an important set of incentives for schools. Given the importance of cross-subsidies from the richer to the poorer-but-more-able, this mechanism is strengthened by higher inequality as the richer have more resources. Cross-national empirical evidence provides support to this view regarding the effect of school selection on segregation (e.g. Alegre \& Ferrer 2010; Jenkins, Micklewright, \& Schnepf 2008; Van de Werfhorst \& Mijs 2010).

There are, then, good reasons to think that marketization will have larger effects where inequality is already higher. What should the political consequences of this be? By assumption, right-wing parties are less sensitive to higher levels of societal inequality than left-wing parties, and so we would expect them to be respond less to inegalitarian concerns about marketization. So, while a right-wing party in a high inequality context would be expected to be less favorable to marketization than one in a low inequality context, ${ }^{3}$ the difference between these two would be smaller than the difference between left-wing parties in these two contexts. Variation in partisan distance on this policy issue should, therefore, be disproportionately driven by variation in left-wing positions.

The theoretical framework thus yields expectations about the policy preferences of political parties over the issue of educational marketization. More specifically, two hypotheses follow naturally.

Hypothesis 1 Where societal inequality is higher, marketization of schooling will be more politically divisive across political parties of the left and right.

Hypothesis 2 The mechanism underlying hypothesis 1 will be explicit concerns from left-wing political actors about the exacerbation of inequality that would result from a policy of marketized schooling.

\footnotetext{
${ }^{3}$ Because the assumption is not that they are completely unresponsive on this issue.
} 


\section{Research Design}

In order to test the predictions of my argument, I employ a paired case study approach. The case selection is driven by a number of considerations. First, as the theory yields hypotheses about the relative levels of partisan contestation over marketizing policies, it is necessary to avoid cases in which such policies were uncontroversial simply because they were irrelevant. While there has clearly been a broad-based rise in the "idea" of marketization as a "policy instrument" (Lindvall 2009), as Jacobs (2009) discusses, elite cognitive processes can lead them to ignore the possibility of some reforms. This was certainly not the case in either Sweden or England and, therefore, they provide appropriate contexts for which to study the politics of marketization.

Second, these cases make it easier to rule out some prominent alternative explations. The Swedish Social Democrat Party (SAP) is generally accepted to have strong left-wing credentials — especially as compared to New Labour in England — which makes it easier exclude a narrow ideological reasoning for the differing outcomes in the two countries. It is conventional wisdom that marketizing policies are inherently right-wing activities, so selecting cases in which one of the left-wing parties is located in an archetypal liberal political economy while the other is enmeshed in one of the most solidly social democratic societies in Europe provides the ideological argument with its least demanding test. That it performs so poorly lends credence to the alternative explanation that I present. A more institutionalist argument has also been suggested by Klitgaard (2008), where he claims that parliamentarism, unicameralism, and a unitary state mean fewer veto players capable of blocking reforms, which facilitates adoption of the marketization agenda relatively unemcumbered. The cases selected here are, however, rather similar in these institutional respects.

Third, the key variable that I propose explains the pattern of party preferences is the prevailing level of societal inequality. As such, it is necessary to select cases that offer variation in this respect, and data on gini coefficients from Solt (2009) make clear that England and Sweden provide an excellent contrast. ${ }^{4}$ Furthermore, there is variation in the extent of social segregation within schools across the two countries - which is the primary channel through which I argue that societal inequality influences political preferences regarding marketization. Jenkins, Micklewright,

\footnotetext{
${ }^{4}$ In 2009, the net income gini coefficient was around 22 for Sweden and around 36 for the UK. This ranked the former as the most equal and the latter as the second most unequal (after the USA) in a sample of 21 commonly-studied advanced industrialized democracies.
} 
\& Schnepf (2008) show that Sweden has amongst the lowest levels of school social segregation in the OECD, while England has middle-to-high levels.

Based on the position of Sweden and England at each end of the cross-national distribution of income inequality, my case selection can be seen as following the "diverse" method and so "probably has stronger claims to representativeness than any other small-N sample" (Seawright \& Gerring 2008: 301). There is a theoretically pragmatic justification for this case selection approach, as well: the theory is not precise enough to say how tight the relationship will be between societal inequality and marketization. As such, selecting cases from each end of the explanatory variable distribution reduces the likelihood of a null finding that is driven by measurement error or the dominance of other explanatory factors, rather than real falsification.

The first hypothesis that I am seeking to test relates to the extent of cross-party divisions over the general policy of marketization in schooling. My approach to this is follow both policy decisions and related political discourses in order to highlight the relative levels of contentiousness surrounding marketization. That is to say, while the primary dependent variable for the study is what might be termed polarization on the issue, it is inevitably necessary to probe this variable with reference to the actual policy decisions that were taken by different governents. To preempt the findings, I take it as inferentially valuable that the Swedish SAP generally accepted and presided over a very much more marketized schools policy than did the British Labour Party. However, the case study approach also makes it possible to test hypothesis 2, related to the underlying causes of policy preferences in these cases — providing what Mahoney (2010: 125) terms, "independent variable causal process observations". Doing so, however, requires shining a light not simply on the presence or absence of inter-party differences, but on the internal policy processes of left-wing parties. At the outset, it should be noted that this kind of analysis will tend to uncover intra-party differences as these organizations are clearly coalitions of individuals with differing perspectives. In this light, the hypotheses are not intended as claims of a uniformity of view within any given party, but rather as claims that the societal context will have an important conditioning effect on which of various tendencies within parties will be stronger. Furthermore, it is important to emphasise that the argument developed above does not require empirical evidence of complete consensus across parties in the Swedish case. Rather, it requires that the difference between the SAP and the centre-right parties in Sweden be smaller than that between Labour 
and the Conservatives in England, and that this be driven by variation on societal inequality across the two countries.

In what follows, I outline the salient details of the schooling system reforms that were considered and adopted across the two countries, as well as presenting data on patterns of school enrollment. I augment this policy comparison with evidence from interviews with policy-makers, as well as published first-hand accounts of their times in office, in order to provide empirical leverage on the causes-of-preferences part of the argument as it relates to left-wing parties. The interviews were conducted both in-person and by telephone during the course of 2012 and 2013. From England, I spoke with a former Secretary of State for Education (Morris 2012), a former Parliamentary Under-Secretary of State for Education (Adonis 2012a), senior policy advisors (Barber 2012; Morgan 2012; Ryan 2012), and a prominently involved MP (Whitehead 2012).

From Sweden, I spoke with two former SAP education ministers (Johansson 2013; Tham 2012), a current SAP education policy advisor (Persdotter 2012), a current and former representative of the teachers' unions (Larsson 2012; Salin 2012), the head of the free school association (Nykvist 2012), and representatives of the Swedish National Agency for Education (Skolverket).

\section{Social Democrat Acceptance in Sweden}

Traditionally, the Swedish schools system was highly centralized and state-centric (Helgøy \& Homme 2006: 14). However, during the 1980s and 1990s, Sweden underwent a series of reforms in education, as well as other policy areas, that were decentralizing. Broadly, the SAP governments of the 1980s concentrated on political decentralization to the municipalities, as well as greater parental involvement in the organization and running of schools (Gustafsson 1987). Expenditure decisions were devolved to local government, as was the employment relationship of teachers much to the consternation of teachers' unions (Lundahl 2002: 690). This decentralization process also came with an explicit aspect of marketization in the form of reforms adopted in 1989 under the SAP. Parents were enabled to express a preference regarding the school that their children would attend and some public money was made available to private schools (Gingrich 2011: 152). Still, it is important not to over-state the extent of marketization conducted by the SAP. Rothstein (1993: 509) describes how there was a clear "no choice" perspective amongst Social Democrats of a more traditionalist orientation. While there were moves in the marketization direction during 
the 1980s, proposals from the (opposition) right-wing parties to introduce school vouchers were not embraced by the government. ${ }^{5}$

Of direct theoretical relevance, much of this reform process was driven by concerns about the efficiency of Swedish welfare provision, especially from the Finance Ministry but also reflecting broader concerns amongst the electorate (Blomqvist 2004: 144-145). Indeed, Pierre (1993: 388) argues that, in the 1980s, it was "the inability to provide key services, combined with goals related to efficiency taking precedence over strictly legalistic goals" that drove the broad pattern of institutional reforms under both the SAP and the centre-right coalition. Similarly, focusing on education, Lundahl (2002: 696) argues that Swedish reforms were a result of, amongst other things, "the necessity to raise the efficiency of education". Efficiency, then, was a core political concern across the political spectrum, and decentralization and marketization were perceived as ways of achieving it. Indeed, this view was explicitly confirmed for education policy by an SAP education minister from the period, who noted during an interview that there was general acceptance of the idea that competition between schools would raise standards (Tham 2012).

The election of a right-wing government in 1991 heralded a further shift towards marketization, which Blomqvist (2004: 145) characterizes as a change where "the former opposition parties sped up the reforms and encouraged private provision more forcefully than the Social Democrats had, but basically continued along the same reform track". In education, a quasi-voucher scheme was introduced so that private schools that met certain regulations, known as "free schools", became entitled to $85 \%$ of per student spending in public schools for each child they taught. Combined with open enrollment, the competitive environment of Swedish schooling was therefore enhanced.

One inferential concern about the claim that the Swedish free school reform was relatively less politically divisive across the left-right dimension (than in the English case) is that it was conducted by a centre-right government - and so does not an embrace of free schools and vouchers on the part of the left. Two features of the policy history are relevant here. First, it is important to note that it was the SAP that introduced school choice in the period before the centre-right government came to power in 1991. It is partly for this reason that a long-serving official at the main teachers' union, Lärarförbundet ${ }^{6}$ argued that free schools are part of a process

\footnotetext{
${ }^{5}$ Although both the prime minister (Ingvar Carlsson) and finance minister (Kjell Olof Feldt) were positively disposed to the idea. I am grateful to a reviewer for making this point.

${ }^{6}$ Lärarförbundet is well-recognised as SAP-leaning, as compared to the second largest teachers' union, Lärars Riksförbund (LR), which is generally held to lean more towards the Liberals (Salin 2012).
} 
of educational reform that was started by the SAP under Ingvar Carlsson and Göran Persson and so, "It's not correct [that it is] an idea from the right-wing" (Larsson 2012). That is not to say that the free school reform was without controversy - either between parties or within the SAP. Rather, it is to say that a professional observer from a traditionally SAP-aligned teachers' union saw a common thread between the programmes of the two parties in this period.

Still, the SAP's parliamentary opposition to the policy when the right-wing government proposed it could be seen as awkward for the argument advanced here. One response to this potential critique is to note that it is common and explicable for parliamentary oppositions to oppose government initiatives, notwithstanding their basic policy preferences (Dewan \& Spirling 2011; Spirling \& McLean 2007). Consistent with this interpretation, while parliamentary records from the period of the reform indicate disagreement with features of the free schools policy on the part of SAP legislators, they also indicate an acceptance - but not necessarily a wholehearted embrace — of the principle of the policy. For example, a committee report on the government's free school bill indicated SAP opposition on the grounds that (Riksdagen 1992c): municipalities should have an influence on the free schools to which they would be transferring money; the $85 \%$ per pupil funding figure was too generous; social need should be factored into financial allocations, ${ }^{7}$ and; the ability to top-up funding with school fees would lead to segregation. The first two of these potentially have element of an anti-marketization position, but they also concede the point that municipalities would indeed provide funds to private operators. As we shall see, the other two are not inconsistent with marketization. ${ }^{8}$ Similarly, a parliamentary motion tabled early in 1992 discussed problems that arise from uniform per pupil funding within municipalities — for which they requested adjustments to the policy — not the issue of marketization or private provision, itself (Riksdagen 1992a). A few months later, a motion put down by many SAP members, including party leader Ingvar Carlsson, took a similar tack in asking the government to make changes to the way private schools receive public funding in order to avoid outsized profits, not to remove them from the system (Riksdagen 1992b). Finally, late in the parliamentary period, school choice was re-asserted as SAP party policy (Riksdagen 1994b) — consistent with the view that "universalism and choice can be combined" (Rothstein 1993: 509). Indeed, while he pointed to the "no choice" element of the SAP in the 1980s, Rothstein (1993: 511) also discerned movement away from this

\footnotetext{
${ }^{7}$ Also see subsequent interventions on this theme (Riksdagen 1994a,b).

${ }^{8}$ They were also addressed by the subsequent SAP government.
} 
position amongst Social Democrats in the early 1990s.

Even if one were to doubt the argument and evidence of the previous paragraph regarding the SAP's initial opposition to the free school policy, their actions upon returning to power in 1994 are telling. At this point, the new SAP Minister for Education explicitly sought crossparty support in schools policy because the "purpose was to make [an] agreement that could hold for a long time" (Johansson 2013). The cross-party agreement was built upon the acceptance of the fundamentals of marketization, but with the introduction of further regulations that were intended to minimize any outstanding risks of economic and social segregation, in keeping with the parliamentary motions noted above (Johansson 2013). At this point, it is critical to note that the important point is not that members of the SAP placed emphasis on the continued avoidance of inequality, but that they felt able to achieve this within the context of a broadly marketized policy framework. That is, the theoretically important comparison for my purposes is less between the SAP and the Moderates, but between the SAP and the British Labour Party — which will become more apparent below.

Under the SAP, the free school policy was changed so that parents could no longer pay extra fees on top of the state-provided funding, the schools were brought under a more unified regulatory framework for curriculum and teacher training, and schools were precluded from choosing students rather than students choosing schools. There were also changes to the funding model to account for the costs of educational services provided at the municipal level (Gingrich 2011: 154), and an explicit shift was made so that per student funds going to schools were weighted by metrics of social need so as to counteract any incentives for school segregation (Johansson 2013). Johansson (2013) indicated that she retained some concerns about the possibility for segregation that could arise from school choice, but this seems to have been related to the possibility that religious schools — which were politically difficult to remove from the system - could provide a backdoor opportunity for selection-by-schools that had otherwise been banned. There were reforms under the SAP, then, but the essential features of a national-scale quasi-voucher schooling system with school choice and private provision — including for-profit providers — were retained. In comparative context, this is truly remarkable. Furthermore, notwithstanding the reasons for the adjustments to the marketized system, the point that concern for inequality in education was at a relatively low ebb has been made before. Discussing education policy across a 25-year period, 
Lundahl (2002: 696) concluded that, "Even if the equality goal of education was never abandoned, it may be questioned to what extent it was actually at the core of the education reforms of the 1990s".

While it has evolved since these reforms in the early and mid 1990s, the underlying foundations of the Swedish education system have remained fairly consistent since then. At the end of 12 years of SAP rule, Helgøy \& Homme (2006: 16) noted that, “'competition', 'privatization', 'consumerism', 'free choice', 'effectiveness' and 'goal orientation' are vital elements in the Swedish education". The cross-party agreement on free schools remains in place right up to the present day. Indeed, as recently as May 2013, the governing centre-right parties came to agreement with the opposition SAP and the Greens on a selection of reforms to the free schools policy that keeps it intact, but provides for some added safeguards relating to inspections and staffing. As reported, this agreement was sought by all parties "to ensure that reforms survived a potential shift in power over time" (The Local 2013). A policy advisor to the SAP notes that there does remain some opposition to free schools within the party, but the numbers are diminishing - due to a mixture of ideological changes and "results" (Persdotter 2012). Indeed, the free school association are not worried about the possibility of the SAP's Education spokesperson, Ibrahim Baylan, becoming the minister for education (Nykvist 2012).

The major political issue surrounding free school policy is profit-making by private operators, rather than the existence of these schools or the model within which they operate. This issue has been of importance both within the SAP (Persdotter 2012) and in the media more generally (Arreman \& Holm 2011: 233). However, two recent SAP congresses have expressed their support for retaining the opportunity to profit for free school operators. The most recent such endorsement came in April 2013, where the acceptance of profit-making was combined with the idea that a proportion of expenditure must be directed towards staffing costs. In the face of this broad political acceptance, it seems that Lärarförbundet has chosen not to challenge the notion of profit-making in the publicly-funded schools, but rather to lobby for teacher/student ratios as direct quality measures - thus embedding an explicit 'more teachers is better' ideology into the system. As their spokesperson put it, "We are not against profits, but we have said all the time that education must be focused on quality" (The Local 2010).

In sum, the policy history in Sweden in the 1980s and 1990s is one that is very much in keeping 
with the prediction that marketization will be far less politically polarizing when inequality is relatively low (hypothesis 1). Furthermore, the underlying logic as to why this should be so is fairly evident from the Swedish case. The theoretical connection to inequality is empirically supported by the relative downplaying of concerns about inequality on the left (hypothesis 2). As discussed, while inequality and segregation were not absent as a policy issue - especially for the SAP — the important point is that it was not so strong a consideration that it made a national voucher-based schooling system unacceptable to the left-wing political actors. The contrast, in this respect, with the English case (discussed below) is stark.

It should be noted, however, that inequality is not entirely absent from the current debate surrounding free schools. Especially on the left of the SAP, there is a perception that the policy has led to an increase in school segregation (Persdotter 2012; Tham 2012). ${ }^{9}$ One response by the party has been to argue for more socio-economic weighting in per-student funding formulas to be written into law (Persdotter 2012). Another has been to propose that over-subscribed schools should allocate spaces on the basis of a lottery so that it is more difficult for successful schools to "creamskim'. ${ }^{10}$ Both of these reforms, though, are within the prevailing model, rather than rejections of it. Interestingly for my theoretical account, this increase in concerns regarding segregation has occurred as Swedish societal inequality itself has been rising. This is less apparent in the gini coefficient than it is in top-income shares, where that of the top $10 \%$ has risen from around $23 \%$ in 1990 to around $28 \%$ in 2010 (Alvarez et al. 2012). While this fits with the theoretical argument, it is too early to be definitive about this temporal aspect of the inequality-marketization connection in Sweden.

\section{Labour Concerns and Inequality in England}

Like Sweden, England since the 1980s has a history of prominent reforms to the structures of educational provision. Unlike Sweden, these have been a source of inter-party political conflict and subsequent policy reform upon changes of government. The Education Reform Act 1988 was passed by a Conservative government, and is generally held to be a landmark reform of English education. One of its most prominent features - and of direct theoretical relevance here — was

\footnotetext{
${ }^{9}$ The empirical evidence regarding this purported relationship is more equivocal (e.g. Böhlmark \& Lindahl 2012; Lindbom 2010).

${ }^{10}$ This is not popular with free schools themselves (Nykvist 2012).
} 
the introduction of an institutional form known as the "grant maintained" (GM) school. Schools of this type were made almost completely independent of local education authorities (LEAs) and received their funding direct from central government in the form of a 'grant'. Under this model, boards of school governors and head teachers were empowered to, among other things, set their own employment terms and admission policies. Such schools, therefore, had similarities with the Swedish free schools, albeit for-profit companies were not able to participate in the English system. ${ }^{11}$

Even before GM schools, the Conservative government had already introduced another notable policy reform in this area. Indeed, the first education reform that the Thatcher government introduced, in 1980, was the Assisted Places Scheme. This provided state money for academically able children to attend fee-funded private schools. The subsidy was means-tested such that full fee remission was available for those from families on very low incomes, but less for those on higher incomes. While there is a redistributive element to this model, it was long highly unpopular on the left as it was effectively targeted at a very limited subset of those children in otherwise poor schools, and constituted an undermining of principles of comprehensive education and state provision. Indeed, Whitty, Power, \& Edwards (1998: 239) note that those on the right "progressively redefined the scheme as the first in a series of measures to stimulate market forces within the English educational system".

In opposition, the Labour Party repeatedly expressed opposition to both the Assisted Places Scheme and GM schools, and when they came to power in 1997, both were quickly scrapped. Some may express surprise at the mechanism chosen to end the GM policy: the introduction of "foundation" schools, presuming that they were not as big a break from the prior policy as might have been expected. Nonetheless, this new type of school was subject to much greater control by LEAs, including in the sphere of staffing, and a national school admissions scheme was introduced that reduced the possibility of selection-by-school. In this sense, there was a notable shift in policy in a traditionally left-wing direction as selection was reduced and the evolving separation of 'successful' state schools and students from their 'less successful' counterparts was stopped. This much is very consistent with hypothesis 1 , and also accords with the more inputrelated changes that are evident from the period, where public expenditure on education jumped

\footnotetext{
${ }^{11}$ One notable difference is that GM schools were conversions from existing maintained schools, while Swedish free schools were new entrants. The comparison, then, should not be pushed too far.
} 
from around $4.5 \%$ of GDP in 1999 to around $5.7 \%$ by the time the Labour government left office in $2010 .{ }^{12}$

Beyond these high profile initial reforms and the infusion of public funding into the school system that began, the most prominent Labour policy change that followed is the adoption of the Academies programme. As they share some similarities with Swedish free schools, they merit further discussion. I show below that in both scope and intent, the Labour Academies are fundamentally different from both the Swedish free schools and from subsequent Conservative/LiberalDemocrat policy after 2010. In short, Labour's academies were targeted at poorer areas and the scheme was explicitly a vehicle for large scale redistributive investment. Furthermore, in withinparty discussions about the policy, clearly expressed concerns regarding its potential impact on inequality meant that the Academy model was not rolled out beyond these targeted areas.

By the end of its first term, the Labour government turned attention in earnest to educational structures that could be used to improve the performance of schooling in deprived areas. Adonis (2012b) provides a very detailed account of the Academy programme that became an embodiment of this principle. Given that, I focus only on the theoretically consequential aspects of the policy process, here. Academies themselves had important similarities to GM schools: direct funding from central government; independence from LEAs; greater freedom over curriculum and pedagogy; and the ability to opt-out of centralized employment bargains. In these ways, they were also similar to Swedish free schools, albeit without the option to be for-profit. These features were intended to provide new school management - supported by sponsors from the private and philanthropic sectors — with the freedoms to make dramatic changes that would allow them to turn around failing schools. To be clear, in contrast to the Swedish case, it was the educational failures in the worst schools that justified these exceptional freedoms - and only in those worst schools. The model was that sponsors would supply $£ 2$ million (or approximately 10\%) of the capital funding for each school, with central government providing the rest (Curtis et al. 2008: 22). Thus, one major feature of the Academy programme was as a channel for large capital investment into poorer areas.

While the redistributive feature of the Academies policy is well recognized, there are further aspects of the policy process within the Labour government that shed some helpful light on the theoretical account that I advance. There was a clear division within the Labour Party,

\footnotetext{
${ }^{12}$ Data from Eurostat.
} 
up to the most senior reaches of the government, on the issue of Academies - albeit one that became entangled with the leadership struggle between the 'Blairite' and 'Brownite' factions (Adonis 2012a; Morgan 2012). For two participants in a concerted, and successful, attempt to steer schools policy from the Labour backbenches in 2006, school admissions policies were "key" to the distributive consequences of any policy (Morris 2012) and it was important to keep LEAs involved in this process to ensure equity (Whitehead 2012).

Furthermore, Whitehead (2012) saw the proposed 2006 "trust school" reform - termed "academies-lite" by Adonis (2012b: 77), but potentially affecting a far larger number of schools as a tantamount to a dismantling of LEAs. In what became a very influential organized response to the "Higher Standards, Better Schools for All" white paper that proposed the trust school reform, these concerns regarding the potential for an expansion of school choice and 'market' entry by new schools were clearly stated by four prominent Labour MPs (Morris et al. 2006: 1).

The fundamental concerns of many colleagues centre around the potential for pupils from poorer areas being disadvantaged as popular schools expand, and wealthier and better informed parents are able to set up their own schools operating their own admissions policies.

With mounting support within the parliamentary party for the positions set out by this group, the "trust school concept was watered down significantly between conception and enactment" (Adonis 2012b: 77). Morris (2012) found that these reforms were "just right" and that she and her colleagues had "stopped" Labour from going in a direction that had the potential to increase educational inequality. To be clear, though, the opposition to wider roll-out of the Academies model did not imply opposition to Labour's Academies as targeted on areas of deprivation (Morris 2012; Whitehead 2012).

In sum, there are three important points to note from this process of policy-making. First, Labour reformed away high profile parts of education policy that they inherited from the Conservatives as they went too far in the direction of privatized marketization that they feared would exacerbate educational inequality. Second, the rollout of the Academies scheme - itself designed to be redistributive - was explicitly limited. Third, one of the key reasons for the restricted rollout was concern within the Labour Party about connections between marketization and inequality. In these ways, hypothesis 1 finds good support in terms of both the policy choices of the 
Labour Party and the comparison of policy choices between Labour and the SAP. Hypothesis 2 also finds support from the underlying reasoning that Labour had for these policy choices.

\section{Conservative Revolution in England}

The coalition government of Conservatives and Liberal Democrats engaged in an early flurry of activity in the area of schools policy when it came into office in May 2010. The Academies Act 2010 was passed with some haste in June 2010 so as to enable swift Academy expansion and development of the English version of "free schools" as early as September 2010. However, there is a key distinction between the operation of the policy under Labour and the new Conservative Secretary of State, Michael Gove. To the 'sponsor-led' Academies that Labour had developed and targeted in deprived areas, the new government added 'converter' Academies. This latter type constitutes existing schools that are authorized by the DfE to convert from their old status to that of an Academy, without needing a sponsor. One consequence has been that the many of the most successful schools have removed themselves from LEA control and the various other constraints on operation to do with staffing, admissions, and curriculum that this implied.

This policy change represents a clear break from the Labour policy, and one that brings it more into line with the Swedish free school policy — and has a strong parallel with the old GM school policy that Labour abolished in the late 1990s (Baker 2010). As shown by Hicks (2014), there is a discernible partisanship effect even at the level of individual schools, where those in more Conservative-voting constituencies are around twice as likely to choose to convert to Academy status than those in more Labour-voting seats. The policy thrust becomes even clearer when one considers that the "free schools" that Michael Gove has championed "are actually just academies that do not replace an existing school" (Baker 2010). Taken together, Academies and free schools now constitute a model of a national education system that bypasses LEAs, increases the involvement of private providers, drastically reduces the importance of nationally-bargained terms and conditions for teachers, and decentralizes various educational decisions.

Hypothesis 1, which clearly sees support, implied that Conservative policy in England would favor marketization. It is not limited to Academies, but is the result of a more general belief that explicitly links marketization and competition to improved educational outcomes. For example, Mr Gove has argued that, "from autonomous schools in Alberta, to Sweden's Free Schools, to the 
Charter Schools of New York and Chicago, freedom is proving an unstoppable driver of excellence" (Gove 2012).

\section{Discussion}

The preceding discussion of the cases can be usefully summarized in order to highlight some the connections between theory and evidence. Table 1 does so by highlighting key parts of the empirical record and indicating the association that each has to the two hypotheses. It demonstrates the range of evidence that relates the cross-national comparison, as well as the underlying causal mechanism of the theory.

\begin{tabular}{|c|c|c|c|}
\hline \multirow[b]{2}{*}{ Period } & \multirow[b]{2}{*}{ Evidence } & \multicolumn{2}{|c|}{ Supports } \\
\hline & & $\mathrm{H} 1$ & $\mathrm{H} 2$ \\
\hline \multicolumn{4}{|c|}{ Sweden } \\
\hline 1989 & $\begin{array}{l}\text { SAP enhanced school choice and made some public money available } \\
\text { to private schools. }\end{array}$ & $\sqrt{ }$ & \\
\hline $1992-1994$ & $\begin{array}{l}\text { SAP adopts parliamentary strategy that broadly accepts free } \\
\text { schools in principle, but seeks implementation adjustments. }\end{array}$ & $\checkmark$ & \\
\hline $1994-$ & $\begin{array}{l}\text { SAP minister explicitly sought cross-party agreement on continua- } \\
\text { tion of free school policy. }\end{array}$ & $\checkmark$ & \\
\hline $1994-$ & $\begin{array}{l}\text { SAP deemed educational equality as compatible with a reformed } \\
\text { free school policy that remained highly marketized. }\end{array}$ & & $\checkmark$ \\
\hline $1994-2006$ & $\begin{array}{l}\text { Free schools sector allowed to expand dramatically under successive } \\
\text { SAP governments. }\end{array}$ & $\checkmark$ & \\
\hline $1994-$ & SAP accepts profit-making for free school providers. & $\checkmark$ & \\
\hline \multicolumn{4}{|c|}{ England } \\
\hline 1997-1998 & $\begin{array}{l}\text { Labour scraps the assisted places and grant maintained schools } \\
\text { schemes over inegalitarian concerns. }\end{array}$ & $\checkmark$ & $\sqrt{ }$ \\
\hline $1997-$ & Labour rejects profit-making for school providers. & $\checkmark$ & \\
\hline $2000-2010$ & $\begin{array}{l}\text { Labour's flagship education policy, Academies, is highly focused on } \\
\text { schools in more deprived areas. }\end{array}$ & & $\checkmark$ \\
\hline 2006 & $\begin{array}{l}\text { Labour's 'Trust school' reform much changed due to concerns about } \\
\text { its potential effects on inequality. }\end{array}$ & $\checkmark$ & $\checkmark$ \\
\hline $2010-$ & $\begin{array}{l}\text { Conservative-led government grants Academy freedoms to a large } \\
\text { and growing portion of schools }\end{array}$ & $\checkmark$ & \\
\hline $2010-$ & $\begin{array}{l}\text { Conservative-led creates Free School programme for new-entry in- } \\
\text { dependent schools. }\end{array}$ & $\checkmark$ & \\
\hline
\end{tabular}

Table 1: Summary of evidence from the Swedish and English cases that supports the two hypotheses.

One outstanding question is how large these free school and Academy sectors are within their 
respective schooling systems, and so how consequential the various policies have been. Unfortunately, school enrollment data is not available for the full period discussed, but interesting comparisons can still be drawn between the development of the Swedish free school and English Academy schemes. Figure 1 plots estimated enrollment percentages for Swedish free schools at the upper secondary level (the short-dashed line that is predominantly higher than the other lines), ${ }^{13}$ as well as actual Academy enrollment percentages for England. Data points colored red denote either Labour or the SAP being the relevant party of government, while blue data points denote right-wing governments. After 2010, I plot the sponsor-led Academies separately from the converter Academies to make clear the effect of the Conservative-led reforms after the change of government, as distinct from the continued roll-out of Labour-initiated sponsor-led Academies.

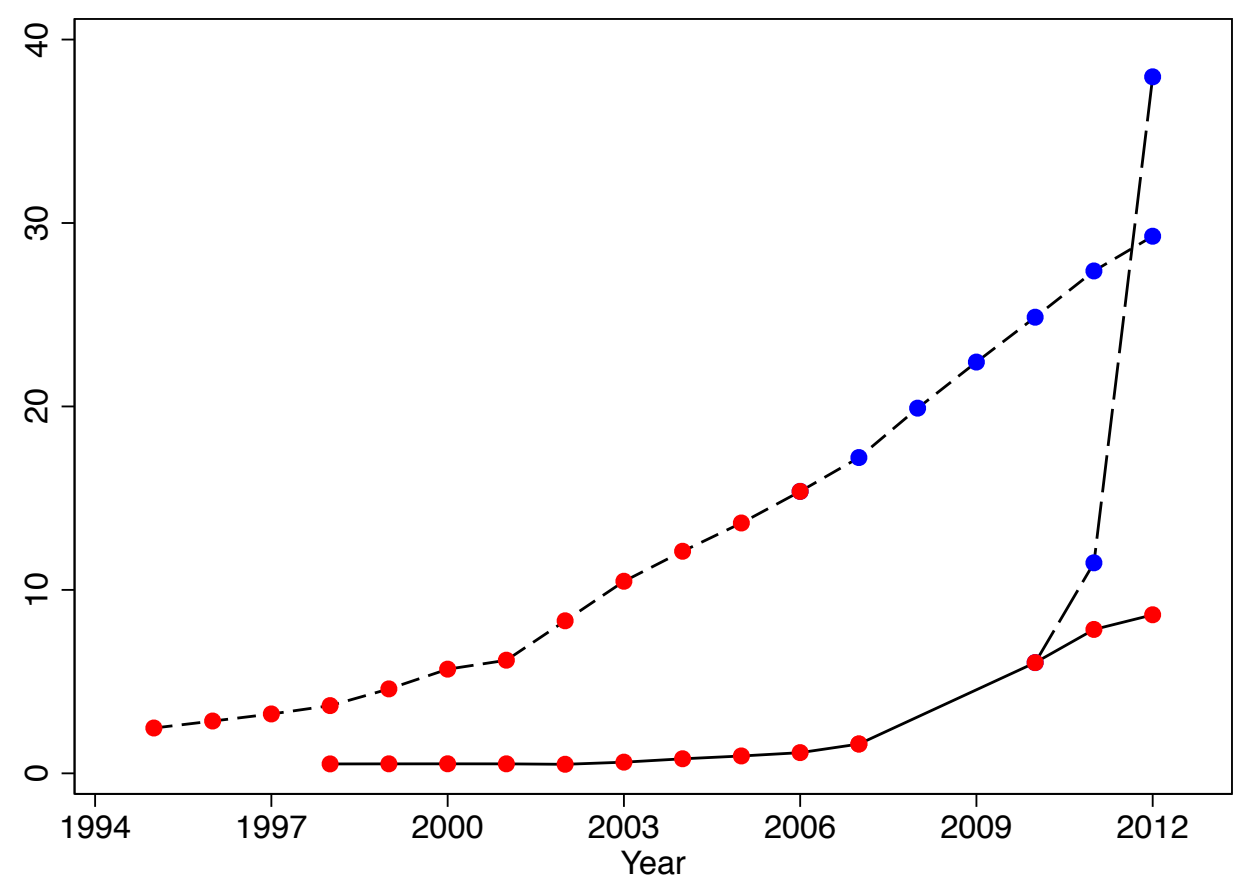

Figure 1: Line plot of the share of free school upper secondary enrollment in Sweden (short-dashed line), the share sponsor-led Academy secondary enrollment in England (solid line), and the share of converter Academey secondary enrollment in England (long-dashed line). Blue (red) data points denote enrollments under respective right-wing (left-wing) governments. [Sources: Skolverket (Swedish National Agency for Education) and the UK Department for Children, Schools and Families.]

The figure nicely illustrates a number of features of the policies in the two countries. First, in Sweden, free schools expanded steadily from 2001 to 2012, and did so in a remarkably consistent

\footnotetext{
${ }^{13}$ Two series for upper secondary enrollment can be constructed from available Skolverket data, and they have slightly different time coverage and values. I regress one on the other and take the one series as well as the predicted values of this regression to construct the measure for the full period.
} 
way under both left- and right-wing governments. This rise has led to the sector educating around $30 \%$ of upper secondary pupils in 2012. Second, Labour's sponsor-led Academies are a much smaller proportion of the English system than free schools are of the Swedish system. This is in keeping with the party's idea that they were aimed at deprived areas experiencing educational failure. By the end of the series, the enrollment figures for sponsor-led academies are approaching those implied by Labour's 400 academy target for the policy. Third, there is a very marked up-turn in the English Academy sector after 2010, which clearly shows the partisan differences in policy-making in this area.

Before concluding, it is important to discuss possible alternative explanations for the pattern of policy-making across the two cases. While I have shown that the theory advanced here fits with the evidence, the findings are all the stronger if the theory out-performs the alternatives. In addition to Klitgaard (2008), discussed above, Zehavi (2012a) also provides an account of the politics of private provision that is based on a veto player foundation, albeit augmented with more explicit consideration of the power of particular interests. Studying Australia, New Zealand, and the USA, he finds that the power of both teachers' unions and the existing private school sector are important determinants of marketization policy. However, for the England-Sweden comparison, these lines of argument work far less effectively. On the one hand, teachers' unions in both countries are similarly strong — with that in Sweden a part of a broad organized labour movement with historically high policy influence. More practically, interviewees in both countries explicitly discounted the importance of the preferences of teachers' unions in the formulation of policy (Adonis 2012a; Barber 2012; Johansson 2013; Morris 2012). On the other hand, it is difficult to argue that the strength of the private school sector in Sweden enabled it to press for more marketization reforms than in England because, prior to the reforms discussed here, the private school sector was considerably larger in England than it was in Sweden.

A broad ideological argument is similarly not able to explain the comparison between England and Sweden. The latter is the archetypal social democratic state where the left has been extremely influential in government and society more generally. Meanwhile, in England, the 'New Labour' government of Tony Blair is generally held as being notably centrist. Thus, a typical model that locates marketizing policy towards the right-hand end of the political spectrum would predict far greater adoption of the policy in England than Sweden. Again, this is not what the evidence 
indicates was the case.

Meanwhile, it is difficult to explain the differences in the cases using the argument, advanced by Klitgaard (2007: 173), that marketization was adopted in response to a "threat to welfare state legitimacy" that resulted from the univeralist character of services. Compulsory education has a universalist character across most countries (Jensen 2011), and certainly including England. Furthermore, immediately prior to the 1997 general election in the UK, "education and schools" was cited as an "important issue facing Britain today" by $43 \%$ of respondents to a MORI poll, second only to the National Health Service (MORI 1997). That is to say, there is clearly evidence of popular dissatisfaction with education policy in the English case, as well.

One alternative account of education policy-making, based on an institutional and somewhat path dependent theory, is offered by Gingrich (2011). She argues that the presence of grammar, and then grant-maintained, schools in England amounted to a fragmentation of the system as they were separated from the rest of the state school organization and that this "fragmented institutional structure of English education allowed the Conservatives to achieve their preference for more choice and preserving elite schools without major cost inflation, while the same structure limited Labour" (Gingrich 2011: 138). However, as she notes, herself, grammar schools formed only a small and geographically circumscribed part of the system (Gingrich 2011: 146). More importantly, while GM schools were indeed separated from local government, Labour swiftly did away with them after they returned to power in 1997. As discussed, the Assisted Places Scheme was also abolished.

Finally, one explanation for why the Swedish case took that course that it did is that the SAP accepted the free schools policy after the fact because there exists a norm of consensusseeking in that political system. However, a number of factors speak against this idea. First, that marketization can have strongly inegalitarian effects and second that voters are highly politically motivated regarding issues that have large distributive consequences for their children. That is to say, if one does not accept the claim made here that lower prevailing inequality leads to smaller consequences from marketization, it would need to be an extremely strong norm of consensus to overcome the potential divisiveness of such a policy. The third point to make here is that, even with a tendency towards a norm of consensus, it was apparently strained to breaking point in the "overhauling the unemployment insurance system [which] was highly contentious, partisan, and 
difficult" (Anderson 2001: 1080). Thus, it seems reasonable to infer that the norm can indeed be overwhelmed by issues with strong distributive consequences.

\section{Conclusion}

The argument presented in this paper offers a novel account of the preferences of political parties regarding the use of choice and markets within the schools system. Adopting a partisan framework that is familiar from a large literature, I show that left-wing parties should tend to be most supportive of market-based educational marketization when societal inequality is low. In a sense, then, where the left is likely to have been most influential, it is most likely to embrace a policy that is often associated with the right. That the argument finds empirical support provides a reason for scholars with traditional views of 'left' and 'right' to pause and reassess. One important implication of this argument is that markets can serve very different political aims in the public sector, depending on the societal context, and it is important to understand how these contexts condition the nature and distribution of political support for their use.

The theoretical emphasis on societal inequality as an explanatory variable points to the possibility of increasing salience of the central claim regarding the connection between educational marketization and educational inequality. As numerous scholars and public figures have noted, we live in a period that has seen dramatic increases in societal inequality across many of the advanced industrialized economies. Given that, the importance of partisan differences over education policy would seem to have the potential to grow in future, as the distributive conflict becomes sharper.

A more positive interpretation of these findings is that they demonstrate that equality and efficiency may not be such awkward bedfellows as Okun (1975) and his followers have assumed - at least in the sphere of the provision of public services. Indeed, Hicks (2013) has recently argued that societal inequality and governmental partisanship combined in important ways that explain the design of the British and Swedish health systems after the Second World War. Thus, it would seem fruitful to pursue the general argument of the conditioning effect of inequality on

policy choice more broadly. The approach appears to have the capacity to explain consequential and counterintuitive patterns of policy-making. 


\section{References}

Adonis, A. (2012a). Telephone interview, June 13.

- (2012b). Education, Education, Education: Reforming England's Schools, London, UK: Biteback Publishing.

Alegre, M. À. \& Ferrer, G. (2010). School regimes and education equity: some insights based on PISA 2006. British Educational Research Journal 36(3): 433-461.

Alvarez, F. et al. (2012). World Top Incomes Database, URL: http://topincomes.g-mond. parisschoolofeconomics.eu/ (Retrieved 02/21/2013).

Anderson, K. M. (2001). The Politics of Retrenchment in a Social Democratic Welfare State: Reform of Swedish Pensions and Unemployment Insurance. Comparative Political Studies 34(9): 1063-1091.

Ansell, B. (2010). From the Ballot to the Blackboard: The Redistributive Political Economy of Education, Cambridge, UK: Cambridge University Press.

Arreman, I. E. \& Holm, A.-S. (2011). Privatisation of public education? The emergence of independent upper secondary schools in Sweden. Journal of Education Policy 26(2): 225243.

Atkinson, A. B., Piketty, T., \& Saez, E. (2011). Top Incomes in the Long Run of History. Journal of Economic Literature 49(1): 3-71.

Baker, M. (2010). Gove's academies: 1980s idea rebranded?, URL: http://www.bbc.co.uk/ news/education-10824069 (Retrieved 09/08/2010).

Ball, S. J. (1993). Education Markets, Choice and Social Class: the market as a class strategy in the UK and the USA. British Journal of Sociology of Education 14(1): 3-19.

Ball, S. J., Bowe, R., \& Gewirtz, S. (1996). School choice, social class and distinction: the realization of social advantage in education. Journal of Education Policy 11(1): 89-112.

Barber, S. M. (2012). Telephone interview, June 19.

Blomqvist, P. (2004). The Choice Revolution: Privatization of Swedish Welfare Services in the 1990s. Social Policy and Administration 38(2): 139-155.

Böhlmark, A. \& Lindahl, M. (2012). "Independent Schools and Long-Run Educational Outcomes — Evidence from Sweden's Large Scale Voucher Reform", CESIfo Working Paper No. 3866. 
Boix, C. (1997). Privatizing the Public Business Sector in the Eighties: Economic Performance, Partisan Responses and Divided Governments. British Journal of Political Science 27(4): 473-496.

Busemeyer, M. R. (2007). Determinants of public education spending in 21 OECD democracies, 1980-2001. Journal of European Public Policy 14(4): 582-610.

Castles, F. G. (1989). Explaining public education expenditure in OECD nations. European Journal of Political Research 17(4): 431-448.

Curtis, A. et al. (2008). "The Academies programme: Progress, problems and possibilities", A report for the Sutton Trust.

Dewan, T. \& Spirling, A. (2011). Strategic Opposition and Government Cohesion in Westminster Democracies. American Political Science Review 105 (02): 337-358.

Epple, D. \& Romano, R. E. (1998). Competition between Private and Public Schools, Vouchers, and Peer-Group Effects. American Economic Review 88(1): 33-62.

Gamble, A. (1988). Privatization, Thatcherism, and the British State. Journal of Law and Society 16(1): $1-20$.

Gingrich, J. R. (2011). Making Markets in the Welfare State: The Politics of Varying Market Reforms, Cambridge, UK: Cambridge University Press.

Gove, M. (2012). Speech on academies, Delivered at Haberdashers' Aske's Hatcham College, London., URL: http://www. education.gov.uk/inthenews/speeches/a00201425/michaelgove-speech-on-academies (Retrieved 03/18/2013).

Gustafsson, L. (1987). Renewal of the Public Sector in Sweden. Public Administration 65(2): $179-193$.

Helgøy, I. \& Homme, A. (2006). Policy Tools and Institutional Change: Comparing education policies in Norway, Sweden and England. Journal of Public Policy 26(2): 141-165.

Hicks, T. (2013). Partisan Strategy and Path Dependence: The Post-War Emergence of Health Systems in the UK and Sweden. Comparative Politics 45(2): 207-226.

- (2014). Partisan Governance and Policy Implementation: The Politics of Academy Conversion Amongst English Schools. Public Administration 92(4): 995-1016.

- (2015). "Acting Right? Privatization, Encompassing Interests, and the Left". 
Iversen, T. \& Stephens, J. D. (2008). Partisan Politics, the Welfare State, and Three Worlds of Human Capital Formation. Comparative Political Studies 41(4-5): 600-637.

Jacob, B. A. \& Lefgren, L. (2007). What Do Parents Value in Education? An Empirical Investigation of Parents' Revealed Preferences for Teachers. Quarterly Journal of Economics 122(4): $1603-1637$.

Jacobs, A. M. (2009). How Do Ideas Matter?: Mental Models and Attention in German Pension Politics. Comparative Political Studies 42(2): 252-279.

Jenkins, S. P., Micklewright, J., \& Schnepf, S. V. (2008). Social segregation in secondary schools: how does England compare with other countries?, Oxford Review of Education 34(1): 21-37.

Jensen, C. (2011). Capitalist Systems, Deindustrialization, and the Politics of Public Education. Comparative Political Studies 44(4): 412-435.

Johansson, Y. (2013). Telephone interview, March 28.

Klitgaard, M. B. (2007). Why are they doing it? Social democracy and market-oriented welfare state reforms. West European Politics 30(1): 172-194.

- (2008). School Vouchers and the New Politics of the Welfare State. Governance 21(4): 479498.

Ladd, H. F. (2002). School Vouchers: A Critical View. Journal of Economic Perspectives 16(4): $3-24$.

Larsson, A.-C. (2012). Personal interview, May 9.

Lindbom, A. (2010). School Choice in Sweden: Effects on Student Performance, School Costs, and Segregation. Scandinavian Journal of Educational Research 54(6): 615-630.

Lindvall, J. (2009). The Real But Limited Influence of Expert Ideas. World Politics 61(4): 703730.

Lundahl, L. (2002). Sweden: decentralization, deregulation, quasi-markets — and then what?, Journal of Education Policy 17(6): 687-697.

Lupu, N. \& Pontusson, J. (2011). The Structure of Inequality and the Politics of Redistribution. American Political Science Review 105(02): 316-336.

Mahoney, J. (2010). After KKV: The New Methodology of Qualitative Research. World Politics 62(1): 120-147.

Morgan, S. (2012). Telephone interview, December 5. 
MORI (1997). Political Attitudes in Great Britain, January 1997, MORI Political Monitor survey for The Times.

Morris, E. (2012). Personal interview, November 5.

Morris, E. et al. (2006). "Shaping the Education Bill: Reaching for Consensus".

Nykvist, C. (2012). Personal interview, May 10.

Okun, A. M. (1975). Equality and Efficiency: The Big Tradeoff, Washington D.C.: Brookings Institution.

Persdotter, K. (2012). Personal interview, May 9.

Pierre, J. (1993). Legitimacy, Institutional Change, and the Politics of Public Administration in Sweden. International Political Science Review 14(4): 387-401.

Riksdagen (1992a). Motion med anledning av prop. 1991/92:95 Valfrihet och fristående skolor, Motion 1991/92: Ub65, URL: http : / www . riksdagen . se/sv/Dokument-Lagar/Ovrigadokument / Ovrigt - dokument / med - anledning - av - prop - 199192 _GF02Ub65/ (Retrieved $04 / 02 / 2014)$.

- (1992b). Motion med anledning av prop. 1992/93: 50 Atgärder för att stabilisera den svenska ekonomin, Motion 1992/93: Fi35, URL: http://www.riksdagen . se/sv/Dokument Lagar/Ovriga-dokument/Ovrigt-dokument/med-anledning-av-prop-199293_GG02Fi35/ (Retrieved 04/02/2014).

- (1992c). Utbildningsutskottet 1991/92:UbU22: Fristående skolor, Committee report on Government Bill 1991/92: 95, URL: http : / / www . riksdagen . se / sv / Dokument - Lagar / Utskottens-dokument/Betankanden/Fristaende-skolor_GF01UbU22/ (Retrieved 11/28/2014).

- (1994a). Resurstilldelning till friskolor, Motion 1993/94: Ub341, URL: http : / / www . riksdagen.se/sv/Dokument-Lagar/Ovriga-dokument/Ovrigt-dokument/Resurstilldelningtill-friskol_GH02Ub341/(Retrieved 04/02/2014).

- (1994b). Skolpengen m.m. Motion 1993/94: Ub325, URL: http : //www . riksdagen . se / sv / Dokument - Lagar / Ovriga - dokument / Ovrigt - dokument / Skolpengen - mm_GH02Ub325/ (Retrieved 04/02/2014).

Rothstein, B. (1993). The Crisis of the Swedish Social Democrats and the Future of the Universal Welfare State. Governance 6(4): 492-517.

Ryan, C. (2012). Personal interview, June 12. 
Salin, S. (2012). Personal interview, May 8.

Seawright, J. \& Gerring, J. (2008). Case Selection Techniques in Case Study Research: A Menu of Qualitative and Quantitative Options. Political Research Quarterly 61(2): 294-308.

Solt, F. (2009). Standardizing the World Income Inequality Database. Social Science Quarterly 90(2), SWIID Version 3.1, December 2011: 231-242.

Spirling, A. \& McLean, I. (2007). UK OC OK? Interpreting Optimal Classification Scores for the U.K. House of Commons. Political Analysis 15(1): 85-96.

Teske, P. \& Schneider, M. (2001). What Research Can Tell Policymakers about School Choice. Journal of Policy Analysis and Management 20: 609-631.

Tham, C. (2012). Personal interview, May 10.

The Local (2010). Sweden looks at limits for profit-making schools, URL: http://www.thelocal. se/29746/20101021/ (Retrieved 10/22/2010).

- (2013). Swedish parties agree to major free-school reform, URL: http://www.thelocal.se/ 48090/20130523/ (Retrieved 06/27/2013).

Van de Werfhorst, H. G. \& Mijs, J. J. (2010). Achievement Inequality and the Institutional Structure of Educational Systems: A Comparative Perspective. Annual Review of Sociology 36(1): 407-428.

Volscho, T. W. \& Kelly, N. J. (2012). The Rise of the Super-Rich: Power Resources, Taxes, Financial Markets, and the Dynamics of the Top 1 Percent, 1949 to 2008. American Sociological Review 77(5): 679-699.

Whitehead, A. (2012). Personal interview, November 8.

Whitty, G., Power, S., \& Edwards, T. (1998). The assisted places scheme: its impact and its role in privatization and marketization. Journal of Education Policy 13(2): 237-250.

Zehavi, A. J. (2012a). Veto Players, Path Dependency, and Reform of Public Aid Policy Toward Private Schools: Australia, New Zealand, and the United States. Comparative Politics 44(3): 311-330.

- (2012b). Welfare State Politics in Privatization of Delivery. Comparative Political Studies 45(2): 194-219. 